\title{
Pengembangan Modul Pelatihan Model Pembelajaran BCCT Bagi Guru dan Kepala Taman Kanak-Kanak
}

\author{
Herminayu ${ }^{\varpi_{1}}$, Bambang Suteng Sulasmono ${ }^{2}$ \\ Manajemen Pendidikan, Universitas Kristen Satya Wacana \\ DOI: $10.31004 /$ obsesi.v4i2.512
}

\begin{abstract}
Abstrak
Penelitian ini bertujuan mengembangkan modul pelatihan model pembelajaran BCCT dalam upaya peningkatan kompetensi pedagogik dan profesional Guru dan Kepala TK. Jenis penelitian adalah penelitian pengembangan dengan menggunakan model pengembangan Sugiyono, yaitu potensi dan masalah, pengumpulan data, rancangan produk, validasi desain, revisi desain, pembuatan produk, uji coba terbatas, dan revisi produk.. Subjek penelitian 30 orang, terdiri 4 orang pada tahap potensi dan masalah, sedang 26 orang pada tahap uji coba terbatas. Data dikumpulkan dengan menggunakan wawancara, observasi, angket dan tes. Analisis data kualitatif dilakukan pada tahap potensi dan masalah, sedangkan analisa kuantitatif dilakukan pada tahap uji coba terbatas dengan data hasil eksperimen. Hasil penelitian menunjukkan pelatihan yang pernah dilakukan belum efektif karena tidak menggunakan modul pelatihan. Validasi ahli menghasilkan modul pelatihan model pembelajaran BCCT dengan kategori sangat baik dan pada tahap uji coba terbatas menunjukkan adanya perbedaan pengaruh penggunaan modul, lebih meningkatkan kompetensi peserta pelatihan dibanding pelatihan tanpa menggunakan modul yang dihitung dari nilai pre test dan post test peserta.
\end{abstract}

Kata Kunci: guru dan kepala tk; model pembelajaran bcct; modul pelatihan.

\begin{abstract}
This study aims to develop training modules for the BCCT learning model in an effort to improve the pedagogical and professional competence of Teachers and Kindergarten Heads. This type of research is development research using Sugiyono's development model, namely potential and problems, data collection, product design, design validation, design revision, product manufacture, limited testing, and product revision. The research subjects were 30 people, consisting of 4 people at the stage potential and problems, while 26 people at the trial phase are limited. Data were collected using interviews, observations, questionnaires and tests. Qualitative data analysis is performed at the potential and problem stage, while quantitative analysis is carried out at a limited trial stage with experimental results. The results showed that the training that had been conducted had not been effective because it did not use training modules. Expert validation produced training modules for the BCCT learning model in very good categories and in the limited trial phase showed differences in the influence of the use of modules, increasing the competency of trainees compared to training without using modules which were calculated from the participants' pre-test and post-test scores.
\end{abstract}

Keywords: teacher and head of kindergarten; bcct learning model; training module.

Copyright (c) 2020 Herminayu, Bambang Suteng Sulasmono

$\triangle$ Corresponding author :

Email Address : herminayu@gmail.com (Salatiga, Indonesia)

Received 6 April 2020, Accepted 14 April 2020, Published 15 March 2020

1112 | Jurnal Obsesi : Jurnal Pendidikan Anak Usia Dini, 4(2), 2020 


\section{PENDAHULUAN}

Guru yang professional dan berkompeten sangat dibutuhkan untuk menghadapi tantangan perkembangan pendidikan yang berjalan terus-menerus ke arah kemajuan. Sebab tanpa kehadiran guru yang professional dan kompeten di sekolah, pendidikan tidak akan mencapai tujuan yang diharapkan. Guru merupakan seseorang yang diberikan wewenang serta tanggung jawab dalam mendidik siswa-siswinya, baik secara pribadi maupun dalam satu kelas, selama di lingkungan sekolah maupun di luar sekolah (Ametembun 2015 : 33). Artinya kompetensi dasar harus dimiliki seorang guru sebagai bentuk wewenang dan kemampuan agar tugas dapat dijalankan dengan sebaik-baiknya. Untuk itu pemahaman tentang kompetensi seorang guru dapat dipahami bahwa seorang guru memiliki kemampuan dari berbagai segi, baik dari segi pengetahuan, ketrampilan juga tanggung jawab bagi siswa-siswi yang dididiknya, sehingga seorang guru dapat melaksanakan tugasnya dengan baik.

Masalahnya, merosotnya mutu pendidikan bukan hanya akibat kurikulum dan ketidakmauan siswa untuk belajar, tetapi juga kurangnya profesionallisme guru dalam proses pembelajaran (Suryana and Fathurrohman 2015 : 39). Seorang guru harus melakukan tugasnya, dan dituntut dapat mengerjakan pekerjaannya secara professional, sehingga tujuan Pendidikan Nasional yakni mencerdaskan kehidupan bangsa dan mengembangkan manusia seutuhnya dapat diwujudkan.

Begitu pentingnya peran guru maka pemerintah selalu berupaya meningkatkan kompetensi dan profesionalisme guru melalui berbagai pelatihan. Beberapa jenis pelatihan yang pernah dilakukan pemerintah seperti: diklat TOT Pola Kerja Terpadu, diklat TOT Umum Kewidyaiswaraan, diklat Sertifikasi dan lain sebagainya (Erawati 2015)). Bahkan untuk diklat Sertifikasi, pemerintah segera membereskan 1,62 juta sertifikasi Guru, dengan harapan dapat meningkatkan kualitas kompetensi dan profesionalisme guru (Petriella. 2019). Akan tetapi sejak tahun 2005 pelaksanaan program pendidikan dan pelatihan (diklat) guru yang diselenggarakan pemerintah dinilai kurang efektif untuk meningkatkan profesionalitas guru (Triananda 2013 dalam Beritasatu.com). Pernyataan ini juga dikemukakan oleh beberapa pakar pendidikan dalam acara Forum Executif Media Indonesia dan Tanoto Foundation dengan judul Peningkatan Kualitas Guru Menuju Profesionalisme di Hotel Crowne Plaza, Jakarta. Sebab pada kenyataannya, $80 \%$ guru memperoleh diklat dari pemerintah dengan komunikasi satu arah dalam bentuk seminar-seminar (Sitepu 2013). Guru-guru dilepas begitu saja tanpa ada pendampingan lebih lanjut setelah pelatihan berakhir. Untuk itu perlu dilakukan program diklat mandiri yang lebih aktif dan mengasah kemampuan guru dalam rangka peningkatan kualitas kompetensi dan profesionalisme guru.

Program pendidikan dan pelatihan merupakan proses pelaksanaan diklat secara terus menerus bagi suatu organisasi agar karyawan dalam hal ini guru yang mengikuti diklat mampu mengembangkan karir dan pekerjaannya, perilaku kerja guru dapat diperbaiki, dan dipersiapkan memegang jabatan yang sulit, serta aktifitas kerja dapat disiapkan sehingga berkembang (Samsudin, 2009). Oleh karena itu, maka perlu dilakukan upaya untuk melaksakan pendidikan dan pelatihan yang berkualitas.

Berdasarkan hasil survey awal P4PT Seni dan Budaya menyatakan bahwa pgogram diklat yang berkualitas meliputi banyak aspek diantaranya : a) kualitas dari program diklat itu sendiri, b) nara sumber yang ditentukan harus berkualitas, c) ditunjang dengan kualitas fasilitas akademis, d) sarana penunjang yang berkualitas, e) layanan yang diberikan juga berkualitas, dan f) proses diklat harus terjaga kualitasnya, sehingga dari diklat yang berkualitas ini dihasilkan guru-guru yang semakin meningkat kompetennya, unggul dalam pembelajaran, dan berprestasi pada bidangnya, serta menguasai teknologi yang tinggi sehingga mampu bersaing di era teknologi yang maju ini (P4TK Seni dan Budaya, 2007-2009 ; (Republik Indonesia 2005,UU RI Nomor 14 Tahun 2005). 
Program pendidikan dan pelatihan yang berkualitas bagi guru bertujuan untuk, yaitu: 1) pengembangan keahlian dan ketrampilan pekerja (guru) sehingga dapat menyelesaikan pekerjaan dengan lebih cepat dan efektif; 2) pengembangan pengetahuan sehingga dapat menyelesaikan tugasnya dengan lebih rasional; 3) pengembangan sikap untuk membangkitkan kemauan untuk bekerja sama dengan rekan kerja dan pimpinan (Jackson dan Marthis 2006). Agar tujuan program pendidikan dan pelatihan tercapai perlu adanya konsep model pelatihan, yang bertujuan sebagai berikut: 1)meningkatkan pengetahuan dan ketrampilan peserta pelatihan, 2) supaya peserta mengalami perubahan secara cepat dan dapat mengikuti perkembangan jaman yang semakin modern termasuk di dalamnya perkembangan model pelatihan. Kemudian setelah kebutuhan pelatihan telah diidentifikasi dan tujuan ditetapkan, pelatih perlu memilih metode pelatihan yang sesuai untuk memenuhi kebutuhan yang dapat mencapai tujuan yang ditetapkan (Desimone \& Harris, 1998 dalam Sarbeng, 2013).

Secara umum, metode pelatihan dapat dikelompokkan ke dalam dua kategori: Metode di tempat kerja (On the Job Training), yang biasanya terjadi di lingkungan kerja normal karyawan; dan metode jauh dari pekerjaan (Off the Job Training) atau ruang kelas, yang biasanya terjadi di luar dari pekerjaan. Pada program pelatihan yang dilakukan kepada Guru dan Kepala TK Yayasan PESAT, menggunakan metode Off the Job Training, karena disesuaikan dengan kondisi dan tempat kerja Guru dan Kepala TK Yayasan PESAT yang tidak berada dalam satu tempat. Selain metode pelatihan yang ditetapkan untuk meningkatkan program pendidikan dan pelatihan, perlu dikembangkan modul pelatihan.

Menurut hasil studi awal dalam penelitian yang berjudul Pengembangan Modul Pelatihan Karya Tulis Ilmiah Hasil PTK Berbasis Andragogi Berbantuan CMS Moodle, menyatakan bahwa penyelengaraan pelatihan, yang sudah dilakukan masih belum efektif meningkatkan kompetensi guru SD dalam penulisan PTK, ditunjukkan dengan peserta pelatihan dalam hal ini guru masih mengandalkan pelatih dan belum mampu untuk belajar dengan mandiri. Selain itu terdapat faktor lain, yaitu metode pelatihan belum dilakukan secara berkesinambungan dan belum menyertakan modul pelatihan (Giarti, 2016).

Hasil studi awal lainnya yang dilakukan melalui wawancara mengenai bahan pelatihan kepada masing-masing satu orang pengawas, kepala sekolah dan guru, dalam Penelitian Pengembangan Modul Pelatihan PTK Berbasis Andragogi Menggunakan Model ADDIE Untuk Meningkatkan Kompetensi Guru SMP Negeri 4 Wewewa Timur (Ngaba 2018). Dari analisis hasil wawancara, ditemukan hasil yang rendah untuk kompetensi guru dalam melakukan dan menulis PTK, terbukti belum ada laporan PTK yang dihasilkan oleh guru walaupun sudah mengikuti banyak pelatihan. Faktor ini disebabkan beberapa hal, yaitu: 1) guru kekurangan sumber belajar, 2) pelatihan yang dilaksanakan tidak efektif, jumlah peserta terlalu banyak (60 peserta dengan 4 orang pelatih), peserta ikut pelatihan sejauh ini hanya untuk memenuhi persyaratan saja, hasilnya peserta belum mampu membuat laporan PTK sebagai salah satu persyaratan mengurus kenaikkan pangkat guru.

Kendala-kendala yang terjadi dalam pelatihan guru dan kepala TK Yayasan PESAT, berdasarkan studi awal yang dilakukan terhadap 4 orang nara sumber, yaitu 1 Supervisor TK, 1 Kepala TK dan 2 Guru TK dalam pelatihan model pembelajaran BCCT yang telah dilakukan, ternyata masih belum efektif dalam penerapannya, terbukti program ini belum sepenuhnya diterapkan di setiap TK. Kendala yang sama dihadapi yaitu: penyampaian materi pelatihan kurang dipahami karena disajikan hanya dalam bentuk power point dan ditampilkan melalui LCD/proyektor, terbatasnya pelatih hanya 1 orang, belum adanya pendampingan baik selama pelatihan maupun setelah pelatihan berakhir. Perlunya modul pelatihan yang digunakan pada saat pelatihan dilaksanakan maupun pada saat pelatihan telah berakhir sebagai buku pedoman atau buku acuan.

Modul diklat merupakan bagian dari bahan yang dapat membantu pelaksanaan diklat. Biasanya digunakan pada waktu proses diklat sedang berlangsung, yaitu sebagai bahan ajar yang dapat berupa buku pegangan untuk pelatih dan juga peserta diklat. Disusun 
secara teratur dan sitematis, di dalamnya terdapat tujuan dan bahan diklat yang diuraikan, serta terdapat latihan dan penilaian terhadap peserta tentang bahan diklat yang dimaksud (Suradji. 2009 : 70).

Untuk itu penelitian ini bertujuan memberikan gambaran pelatihan yang telah dilakukan serta kelemahannya, dan mengembangkan modul pelatihan Model Pembelajaran BCCT dalam upaya peningkatan kemampuan pedagogik dan profesional Guru dan Kepala TK Yayasan PESAT melalui model pengembangan dengan tahapan 1) tahap potensi dan masalah, 2) tahap pengumpulan data, 3) tahap perancangan desain produk, 4) tahap validasi desain oleh ahli dan calon pengguna, 5) tahap revisi desain produk, 6) tahap pembuatan produk modul, 7) tahap uji terbatas model; dan 8) tahap revisi produk (Sugiyono 2017).

\section{METODOLOGI}

Penelitian ini merupakan penelitian pengembangan (Research and Development, bertujuan untuk mengembangkan dan menghasilkan produk berupa modul pelatihan model pembelajaran BCCT bagi Guru dan Kepala TK Yayasan PESAT yang dilakukan di Lopait Kabupaten Semarang mulai bulan September-Maret 2020. Pengembangan dengan model Sugiyono dengan tahapan potensi dan masalah, pengumpulan data, rancangan produk, validasi desain, revisi desain, pembuatan produk, uji coba terbatas, dan revisi produk. Subjek penelitian 30 orang, terdiri 4 orang pada tahap potensi dan masalah, sedang 26 orang pada tahap uji coba terbatas. Data dikumpulkan dengan menggunakan wawancara, observasi, angket dan tes. Analisis data kualitatif dilakukan pada tahap potensi dan masalah, sedangkan analisa kuantitatif dilakukan pada tahap uji coba terbatas dengan data hasil eksperimen, yang terdiri dari 13 orang pada kelas Eksperimen dan 13 orang pada kelas kontrol. Keseluruhannya tahapan dapat digambarkan pada gambar 1.

\begin{tabular}{|c|c|c|c|}
\hline \begin{tabular}{l}
\multicolumn{1}{c}{ Potensi dan } \\
$\quad$ Masalah \\
Analisa kualitatif \\
dengan wawancara \\
dan observasi \\
terhadap 4 orang
\end{tabular} & $\begin{array}{l}\text { Pengumpulan Data } \\
\text { - Sistematika modul } \\
\text { - Modul berdasar model } \\
\text { EDDIE } \\
\text { - Model Pelatihan Of The } \\
\text { Job Training }\end{array}$ & $\begin{array}{l}\text { Rancangan Produk } \\
\text { - Silabus dan } \\
\text { skenario pelatihan } \\
\text { - Materi modul } \\
\text { - Buku Panduam } \\
\text { Pelatihan }\end{array}$ & \multirow{2}{*}{$\begin{array}{l}\text { Validasi Desain . } \\
\text { dengan angket } \\
\text { validasi Ahli: } \\
\text { - Modul } \\
\text { - Desain Silabus dan } \\
\text { Skenario Pelatihan } \\
\text { - Materi Modul } \\
\qquad \\
\end{array}$} \\
\hline & & & \\
\hline $\begin{array}{l}\qquad \text { Revisi Produk } \\
\text { dilakukan berdasarkan } \\
\text { angket penilaian peserta } \\
\text { terhadap materi modul } \\
\text { sehingga dihasilkan } \\
\text { Produk Modul } \\
\text { Pelatihan }\end{array}$ & $\begin{array}{l}\quad \text { Uji Coba Terbatas } \\
\text { Analisa Kuantitatif } \\
\text { dengan Uji Eksperimen } \\
\text { mengukur perbedaan } \\
\text { kompetensi peserta } \\
\text { melalui pre test dan post } \\
\text { test dengan uji t }\end{array}$ & $\begin{array}{l}\text { Pembuatan Produk: } \\
\text { 1. Silabus dan } \\
\text { Skenario Pelatihan } \\
\text { 2. Modul Pelatihan } \\
\text { 3. Buku Panduan }\end{array}$ & $\mid \begin{array}{l}\text { Revisi Desain } \\
\text { - Modul } \\
\text { Pelatihan } \\
\text { - Desain Silabus } \\
\text { dan Skenario } \\
\text { Pelatihan } \\
\text { - Materi Modul }\end{array}$ \\
\hline$\downarrow$ & & & \\
\hline Uji Coba & Revisi Produk & Produk Masal & \\
\hline
\end{tabular}

\section{Gambar 1. Bagan Tahapan Penelitian}

\section{HASIL DAN PEMBAHASAN}

\section{Proses dan Hasil Penelitian Pengembangan}

Proses dan hasil penelitian dikembangkan dengan model Sugoyono yang sejalan dengan model pengembangan ADDIE, karena berorientasi pada sistem, sudah familier di kalangan para praktisi pendidikan, dan langkah-langkahnya lebih sederhana dan sistematik, serta semua kegiatan pembelajaran yang direncanakan berfokus untuk membimbing siswa 
atau pembelajar dalam membangun pengetahuannya (Branch 2009). Tahapan tersebut diuraikan sebagai berikut:

\section{Potensi dan Masalah}

Tahapan ini memberikan gambaran pendidikan dan pelatihan telah dilakukan oleh Yayasan PESAT serta masalah yang dihadapi berkaitan dengan pendidikan dan pelatihan model pembelajaran BCCT yang telah diikuti oleh Guru dan Kepala TK Yayasan PESAT. Tahapan ini dikaji dengan teknik penelitian wawancara dan observasi sehingga dapat menjadi jawaban atas pertanyaan pada rumusan masalah 1 dan 2 pada bab 1 pendahuluan. Wawancara dilakukan pada tanggal 10 September 2019 kepada 1 Supervisor, 1 Kepala TK, dan 2 Guru, sedangkan observasi dilakukan pada bulan September 2019 terhadap 7 TK di wilayah Jawa yang Guru dan Kepala TK telah mengikuti pelatihan model pembelajaran BCCT. Tahapan proses dan hasil penelitian pengembangan sekaligus sebagai jawaban atas rumusan masalah 1 dan 2 , hasilnya sebagai berikut:

\section{Potensi Pendidikan dan Pelatihan}

Potensi pelatihan yang selama ini telah dilakukan Yayasan PESAT sebagai penyelenggara pelatihan model pembelajaran BCCT mengadakan pelatihan dua kali dalam setahun dan memberikan wewenang kepada devisi litbang untuk melaksanakannya. Pelatihan merupakan program tetap yayasan bagi guru dan kepala TK dan dilakukan secara bergilir untuk semua guru dan kepala. Alokasi waktu pelatihan 1 minggu dengan pemberian materi tentang model pembelajaran, pembuatan RPPH dan penilaian disertai presentasi dan praktek mengajar.

\section{Masalah-masalah Pendidikan dan Pelatihan}

Masalah-masalah pelatihan yang selama ini dilakukan menjadi kelemahan dalam pelatihan, yaitu 1) tidak adanya buku/ sumber belajar yang dimiliki guru dan kepala TK, 2) penyampaian materi dalam bentuk power point yang di tayangkan melalui LCD dan peserta menerima print out power point atau soft copy, 3) peserta pelatihan hanya berkesempatan 1 kali untuk mengikuti pelatihan, sedang dalam penerapan tidak adanya mentor atau pendamping, 3) keterbatasan pelatih yang hanya 1 orang dalam mendampingi guru dan kepala TK baik selama pelatihan berlangsung maupun setelah selesai pelatihan.

\section{Pengumpulan Data}

Pengumpulan data hasil studi literatur telah dimuat pada bab 2 kajian pustaka. Peneliti menemukan konsep-konsep atau dasar-dasar teoritis dari berbagai sumber tentang model pembelajaran BCCT yang disusun secara sistematis untuk menghasilkan produk yang akan dikembangkan yaitu modul pendidikan dan pelatihan. Hasil studi literatur, yaitu: pertama, materi pelatihan disusun dalam bentuk modul yang disusun secara sistematis, yang didalamnya terdapat tujuan dan uraian materi, serta adanya penilaian bagi peserta.

Kedua, modul juga perlu dikembangkan dengan model ADDIE karena model pengembangan ADDIE sesuai dengan model pengembangan Sugiyono. Ketiga, program pendidikan dan pelatihan yang akan dilaksanakan menggunakan metode Off the Job Training, yaitu metode pelatihan yang pelaksanaannya dilakukan diluar pekerjaan atau di kelas khusus yang biasanya terjadi jauh dari pekerjaannya. Metode ini dipilih karena sesuai dengan kondisi dan tempat kerja guru dan kepala TK Yayasan PESAT yang tidak berada dalam satu tempat.

\section{Perancangan Desain Produk}

Pengembangan desain modul pelatihan dirancang berdasarkan hasil pengumpulan dalam penyusunan modul pelatihan, diantaranya mencakup rancangan tujuan, susunan materi modul pelatihan, skenario pelatihan, dan evaluasi pembelajaran. Untuk merumuskan 
pengembangan modul pendidikan dan pelatihan model pembelajaran BCCT dengan mengacu pada model pengembangan ADDIE.

Konten materi model pembelajaran BCCT meliputi : unit 1 konsep dasar model pembelajaran BCCT, unit 2 aspek pokok model pembelajaran BCCT, unit 3 permainan dalam model pembelajaran BCCT, unit 4 sentra-sentra model pembelajaran BCCT, unit 5 Rencana Pelaksanaan Pembelajaran Harian (RPPH) dengan model pembelajaran BCCT, unit 6 penilaian peserta didik dengan model pembelajaran BCCT, unit 7 presentasi RPPH dan penilaian peserta didik, unit 8 praktek RPPH dan penilaian peserta didik. Konten materi tersebut dilengkapi dengan aktifitas peserta, tes peserta, dan evaluasi sebagai alat ukur peningkatan kompetensi peserta.

Pada tahap ini perencanaan desain produk yang penulis rancangkan terdiri dari : 1)membuat silabus dan skenario pelatihan, 2)menyusun kerangka materi modul pelatihan, 3) menyusun buku panduan pelatihan. dan 4)merancang alat evaluasi. Rancangan ini sesuai tahap desain perancangan model pengembangan ADDIE, yaitu merancang outline komponen modul yang hendak dikembangkan, kemudian penyusunan sistematika modul yang dikembangkan seperti yang telah di uraikan pada bab 2 dan pada tahapan ini menghasilkan rancangan produk modul pelatihan model pembelajaran BCCT.

\section{Uji Pakar dan Calon Pengguna}

Tujuan memvalidasi desain modul pelatihan oleh validator ahli modul, ahli desain silabus dan skenario pelatihan, ahli materi modul dan calon pengguna untuk menentukan tingkat kelayakan produk modul pelatihan model pembelajaran BCCT yang telah disusun. Hasil validasi dengan lembar angket, yaitu 1) ahli modul sebesar 84\%, dengan saran rumusan indikator dan tujuan yang belum operasional dilakukan perbaikan dengan tujuan supaya operasional; 2) ahli desain modul pelatihan sebesar $86 \%$; dengan saran perbaikan indikator supaya disesuaikan dengan tujuan dengan menggunakan kata operasional yang mengacu pada kata operasional HOTS, perlunya penggunaan media untuk menjelaskan materi modul pelatihan; 3) ahli materi modul pelatihan model sebesar $87 \%$, dengan saran, yaitu : bagian unit 2 dirumuskan kembali sesuai dengan indikator supaya lebih jelas, dan pada bagian unit 4 bentuk kegiatan atau aktivitas dirancang sesuai dengan tujuan dan indikator yang ingin dicapai; 4) calon pengguna sebesar $89 \%$, dengan saran materi modul pelatihan model pembelajaran BCCT dapat dijadikan acuan untuk melakukan perbaikan. Berdasarkan ke empat penilaian kualitas modul dikategorikan sangat baik dan valid, artinya modul layak untuk diuji cobakan dalam pelatihan.

\section{Pembuatan Produk Modul}

Tahap pembuatan produk dari penelitian pengembangan ini yaitu: 1) silabus pelatihan dan skenario pelatihan terdiri bagian silabus pelatihan merupakan garis besar pelatihan yang dirancang sebagai hasil kegiatan pelatihan yang masih dalam bentuk rancangan. Konten silabus pelatihan terdiri dari bagian identitas pelatihan dan uraian yang dirancang sebagai kegiatan pelatihan. Bagian identitas mencakup nama pelatihan, nama yang melatih, kompetensi pelatihan, dan kompetensi dasar pelatihan; 2) modul pelatihan terdiri dari dua modul yakni modul pelatih dan modul peserta. Modul peserta dibagi menjadi tiga, yaitu: bagian pertama terdiri dari bagian judul, kata pengantar, dan daftar isi. Bagian kedua berisikan materi diawali dengan pendahuluan yang berisikan: pengantar, stamdar kompetensi pelatihan, kompetensi dasar yang akan dicapai, tujuan yang hendak dicapai, peta konsep keseluruhan modul, waktu, prasarat, petunjuk penggunaan modul pelatih, dan tujuan akhir. Bagian akhir konten materi dilengkapi dengan aktifitas peserta, test peserta sebagai alat evaluasi peningkatan kompetensi peserta; 3) buku panduan terdiri dari 2 buku, panduan untuk pelatih dan peserta yang digunakan selama pelatihan berlangsung, meliputi bagian pertama yang disebut awal dan bagian ke dua disebut bagian konten. 


\section{Uji Lapangan Terbatas}

Uji lapangan terbatas dilakukan kepada 26 orang, dibagi menjadi dua kelas pelatihan, yaitu 13 orang kelas eksperimen menggunakan modul pelatihan, dan 13 orang kelas kontrol tanpa menggunakan modul pelatihan. Pelaksanaan uji lapangan terbatas diadakan di lokasi Yayasan PESAT Lopait Kabupaten Semarang dengan hasil penilaian pada proses pelaksanaan pelatihan sebagai berikut: 1) hasil angket observasi peserta pelatihan terhadap pelaksanaan pelatihan rata-rata sebesar 93\%, kategori sangat baik dengan tanggapan, yaitu: 2 peserta memberikan tanggapan kurang baik pada aspek keadaan ruang kelas yang digunakan dalam pelaksanaan pelatihan, 1 peserta menanggapi kurang baik pada suhu ruangan proses pelaksanaan pelatihan, 1 peserta berkaitan dengan jadwal pelatihan dilaksanakan sesuai tepat waktu, dan 1 peserta dengan tanggapan kurang baik yang berkaitan dengan jadwal pelatihan sudah sesuai dengan waktu dan tidak mengangu tugastugas peserta; 2) Hasil tanggapan peserta terhadap penilaian materi modul pelatihan ratarata sebesar $94 \%$ dengan kategori sangat baik. Semua peserta memberikan tanggapan sangat baik dam modul pelatihan sangat membantu peserta memahami materi pembelajaran dan mudah untuk diterapkan, Saran berkaitan dengan penulisan huruf yang kurang dan perlu direvisi serta beberapa kesalahan dalam pengetikan untuk diperbaiki; 3) Ada perbedaan pengaruh modul pelatihan terhadap kompetensi peserta melalui pre test dan post test pada kelas eksperimen maupun kelas kontrol yang datanya bersifat homogen dengan nilai signifikan >0,05, dan berdistribusi normal dengan nilai signifikan $>0,05$.

Melalui SPSS 20, diperoleh uji statistic sebagai berikut:

a) Hasil Uji Paired T Test

Kelas eksperimen yang menggunakan modul nilai rata-rata pre test 46,9231 dan pada post test 76,9231 dengan nilai signifikansi sebesar $0,000(\mathrm{P}<0,05)$, terdapat perbedaan pengaruh terhadap pelatihan dengan mengunakan modul (tabel 1). Sedangkan kelas kontrol yang tanpa menggunakan modul nilai rata-rata pre test 42,6923 dan nilai rata-rata 49,2308 dengan nilai signifikansi sebesar 0,169 ( $p>0,05)$, hasilnya tidak terdapat perbedaan pengaruh pelatihan tanpa penggunaan modul terhadap kompetensi peserta; ditunjukkan pada tabel 2 .

Tabel 1. Hasil Uji Paired T Test Kelas Eksperimen

\begin{tabular}{|cc|c|c|c|c|}
\hline & Mean & $N$ & $\begin{array}{c}\text { Std. } \\
\text { Deviation }\end{array}$ & $\begin{array}{c}\text { Std. Error } \\
\text { Mean }\end{array}$ \\
\hline Pair & Pre Test & 46,9231 & 13 & 14,07398 & 3,90342 \\
1 & Post Test & 76,9231 & 13 & 15,07460 & 4,18094 \\
\hline
\end{tabular}

Tabel 2. Hasil Uji Paired T Test Kelas Kontrol

\begin{tabular}{|cc|c|c|c|c|}
\hline & Mean & $\mathbf{N}$ & $\begin{array}{c}\text { Std. } \\
\text { Deviation }\end{array}$ & $\begin{array}{c}\text { Std. Error } \\
\text { Mean }\end{array}$ \\
\hline Pair & Pre Test & 42,6923 & 13 & 11,83487 & 3,28240 \\
1 & Post Test & 49,2308 & 13 & 18,91276 & 5,24545 \\
\hline
\end{tabular}

\section{b) Hasil Uji Independent Sample t-test}

Pada tabel nilai $\mathrm{t}$ hitung adalah sebesar 4,128 dan $\mathrm{t}$ tabel 2,0638, dengan ketentuan $\mathrm{t}$ hitung $>\mathrm{t}$ tabel, Ho ditolak dan H1 diterima artinya ada perbedaan rata-rata post test peserta pelatihan yang menggunakan modul dengan pelatihan yang tanpa menggunakan modul pelatihan (tabel 3 dan tabel 4). 
Tabel 3. Hasil Uji Independent Sample t-test

\begin{tabular}{|c|c|c|c|c|c|}
\hline & Kelompok & $\mathbf{N}$ & Mean & $\begin{array}{c}\text { Std. } \\
\text { Deviation }\end{array}$ & $\begin{array}{c}\text { Std. Error } \\
\text { Mean }\end{array}$ \\
\hline \multirow{2}{*}{ Post Test } & 1 & 13 & 76,923 & 15,0746 & 4,1809 \\
& 2 & 13 & 49,231 & 18,9128 & 5,2455 \\
\hline
\end{tabular}

Tabel 4. Independent Samples Test

\begin{tabular}{|c|c|c|c|c|c|c|c|c|c|c|}
\hline & \multicolumn{2}{|c|}{$\begin{array}{l}\text { Levene's } \\
\text { Test for } \\
\text { Equality } \\
\text { of } \\
\text { Variance } \\
\text { s }\end{array}$} & \multicolumn{7}{|c|}{ t-test for Equality of Means } \\
\hline & & \multirow[t]{2}{*}{$\mathrm{F}$} & \multirow[t]{2}{*}{ Sig. } & \multirow[t]{2}{*}{$\mathrm{T}$} & \multirow[t]{2}{*}{ Df } & \multirow{2}{*}{$\begin{array}{c}\text { Sig. } \\
(2- \\
\text { tailed } \\
)\end{array}$} & \multirow[t]{2}{*}{$\begin{array}{c}\text { Mean } \\
\text { Differenc } \\
\mathrm{e}\end{array}$} & \multirow{2}{*}{$\begin{array}{c}\text { Std. } \\
\text { Error } \\
\text { Differen } \\
\text { ce }\end{array}$} & \multicolumn{2}{|c|}{$\begin{array}{l}\text { 95\% Confidence } \\
\text { Interval of the } \\
\text { Difference }\end{array}$} \\
\hline & & & & & & & & & Lower & Upper \\
\hline \multirow[b]{2}{*}{$\begin{array}{l}\text { Pos } \\
\text { Ttes } \\
\mathrm{t}\end{array}$} & $\begin{array}{c}\text { Equal } \\
\text { variances } \\
\text { assumed } \\
\end{array}$ & 909 & , 350 & 4,128 & 24 & ,000 & 27,6923 & 6,7078 & 13,8480 & 41,5366 \\
\hline & $\begin{array}{c}\text { Equal } \\
\text { variances } \\
\text { not } \\
\text { assumed }\end{array}$ & & & 4,128 & $\begin{array}{r}22,86 \\
3\end{array}$ & ,000 & 27,6923 & 6,7078 & 13,8115 & 41,5731 \\
\hline
\end{tabular}

c) Nilai N gain score.

Jika dilihat dari keefektifannya penggunaan modul pada kelas pelatihan cukup efektif $(56,2 \%)$, sedangkan pelatihan tanpa menggunakan modul tidak fektif $(10,9 \%)$ dari nilai $N$ gain score, pada tabel 5 .

Tabel 5. Hasil Perhitungan Uji N-Gain Score

\begin{tabular}{|c|c|c|c|}
\hline \multirow{2}{*}{$\mathrm{NO}$} & Kls Eksperimen & \multirow{2}{*}{$\mathrm{NO}$} & Kls Kontrol \\
\hline & N-Gain Score (\%) & & N-Gain Score (\%) \\
\hline 1 & 50 & 1 & $-7,69$ \\
\hline 2 & 76,92 & 2 & 72,73 \\
\hline 3 & 70 & 3 & -40 \\
\hline 4 & 16,67 & 4 & 11,11 \\
\hline 5 & 50 & 5 & $-14,29$ \\
\hline 6 & 100 & 6 & 23,08 \\
\hline 7 & 42,86 & 7 & 0 \\
\hline 8 & 75 & 8 & 0 \\
\hline 9 & 37,5 & 9 & 21,43 \\
\hline 10 & 45,45 & 10 & $-8,33$ \\
\hline 11 & 100 & 11 & 33,33 \\
\hline 12 & 35,71 & 12 & 50 \\
\hline 13 & 30 & 13 & 0 \\
\hline \multicolumn{2}{|c|}{ Mean $=56,1627$} & \multicolumn{2}{|c|}{ Mean $=10,8743$} \\
\hline \multicolumn{2}{|c|}{ Minimal $=16,67$} & \multicolumn{2}{|c|}{ Minimal $=-40$} \\
\hline \multicolumn{2}{|c|}{ Maksimal = 100} & \multicolumn{2}{|c|}{ Maksimal=72,73 } \\
\hline
\end{tabular}




\section{Revisi Hasil Uji Lapangan Terbatas}

Revisi hasil uji lapangan terbatas, dilakukan berdasarkan saran peserta pelatihan dari angket tanggapan materi modul pelatihan sebagai berikut : 1) merevisi daftar isi modul pelatihan ditambahkan bagian evaluasi, serta mengganti urutan halaman pada bagian daftar isi; 2) merevisi unit 5 pada bagian tes peserta nomer 2 pilihan jawaban $b$ manfaat diganti peran RPPH, karena ada kesamaan antara jawaban b dan c, yaitu manfaat dan fungsi' 3) memperbaiki kesalahan dalam pengetikan penomoran pilihan jawaban yang seharusnya 1,2,3,4 tertulis 5,6,7,8 pada soal evaluasi nomor 13, dan huruf dalam satu kata, bagian evaluasi nomor 17 jawaban $C$ seharusnya perencanaan tertulis perencaan; 4)memperbaiki bagian format penilaian baik presentasi maupun praktek yang seharusnya skor total penilaian tidak dibagi dengan dengan angka 4, tetapi cukup menjumlahkan saja antara bagian $\mathrm{A}+\mathrm{B}+\mathrm{C}+\mathrm{D}$.; 5) menambahkan gambar yang berwarna agar modul lebih menarik untuk dipelajari.

\section{Pembahasan Hasil Penelitian}

Pengembangan modul pendidikan dan pelatihan model pembelajaran BCCT bagi guru dan kepala TK Yayasan Pesat berdasarkan pada rumusan masalah dengan mengacu pada model pengembangan Sugiyono (2017:48), sampai pada tahapan revisi hasil uji coba lapangan terbatas, terbukti dapat meningkatkan kompetensi peserta pelatihan. Pengujian dilakukan dengan uji statistik Paired T-test terhadap data pasangan kelas menggunakan modul (eksperimen) diperoleh hasil bahwa pre test lebih rendah daripada post test, nilai korelasinya 0.354 artinya mempunyai hubungan kuat dan positif, dan nilai sig. $0,00<0.05$, artinya ada perbedaan masing-masing variabel karena ada perlakuan dengan menggunakan modul. Pada kelas tanpa menggunakan modul (kontrol) nilai korelasinya 0,531 , artinya mempunyai hubungan kuat dan positif, dan nilai sig. 0,169>0.05, artinya pelatihan yang dilakukan tanpa menggunakan modul, tidak ada pengaruh meningkarkan kompetensi peserta pelatihan. Berdasarkan uji independent sample t-test diperoleh hasilnya $\mathrm{t}$ hitung 4,128 > 2,0639 $\mathrm{t}$ table, artinya rata-rata post test kelas menggunakan modul (eksperimen) dengan post test kelas tanpa menggunakan modul (kontrol) ada perbedaan yang signifikan, sehingga uji N-Gain Score dapat digunakan. Pengujian N-gain score dapat disimpulkan penerapan modul cukup efektif $(56,2 \%)$ sedangkan yang tidak menggunakan modul tidak efektif $(10,9 \%)$.

Pada hasil penilaian presentasi mengajar dan praktek mengajar pada kedua kelas pelatihan diperoleh data bahwa kelas yang menggunakan modul pelatihan (eksperimen) dapat meningkatkan kompetensi mengajar peserta, terbukti 4 peserta hasil penilaian sangat baik dan 9 peserta katagori baik. Berdasarkan uraian hasil dan pembahasan membuktikan bahwa penggunaan modul pelatihan model pembelajaran BCCT lebih meningkatkan kompetensi peserta dibanding dengan pelatihan yang tidak menggunakan modul pelatihan. Hasil penelitian ini mengacu pada penelitian yang menunjukkan bahwa penggunaan modul meningkatkan kemampuan pengetahuan peserta pelatihan dibandingkan dengan pelatihan yang tanpa menggunakan modul pelatihan (Ismail, 2009).

Selain itu penggunaan modul pelatihan dapat meningkatkan kompetensi peserta pelatihan dalam menerapkan model pembelajaran BCCT dimana konten materinya tersusun dengan baik sehingga menjadi lebih efektif dan praktis digunakan dalam pelatihan. Pernyataan ini sejalan dengan hasil penelitian yang menunjukkan bahwa penggunaan modul dalam pelatihan sangat efektif dan praktis terutama dalam penyusunan konten materi sehingga dapat meningkatkan kemampuan peserta pelatihan ((Sumarah 2017; Sari, 2017). Sedangkan modul pelatihan model pembelajaran BCCT dengan kualitas cukup baik dapat meningkatkan pengetahuan peserta dan meningkatkan motivasi belajar peserta baik pada saat pelatihan maupun sebagai bahan pembelajaran secara mandiri yang mudah untuk diterapkan. Hal yang sama ditemukan dalam penelitian bahwa modul yang berkualitas dapat meningkatkan ketrampilan pembelajaran peserta pelatihan serta memotivasi belajar 
peserta sehingga peserta mampu mengimplementasikan pembelajaran secara mandiri (Perdana dkk., 2017; Sadimin dkk., 2017; Sathya dkk., 2017).

Hasil penelitian yang lain menemukan bahwa modul pelatihan yang digunakan seharusnya mempunyai kualitas yang baik dan dapat digunakan dalam pelatihan, harus melalui proses pengujian dan revisi oleh para ahli maupun pengguna yaitu peserta pelatihan (Wulandari dkk., 2018); (Bano 2018). Hal yang sama dilakukan terhadap modul pelatihan model pembelajaran BCCT dengan pengujian dan revisi sehingga kualitasnya cukup efektif digunakan dalam pelatihan model pembelajaran BCCT yang dikembangkan (Wulandari dkk., 2018; Bano, 2018). Sedangkan menurut Rindaningsih (2012) pengembangkan model manajemen berbasis pembelajaran BCCT efektif mengatasi permasalahan kompleks di sekolah dan memaksimalkan kepala sekolah dalam menjalankan strategi sekolah.

Berdasarkan uraian di atas dan didukung dengan hasil analisa data menunjukkan adanya perbedaan pengaruh penggunaan modul pendidikan dan pelatihan terhadap kompetensi peserta yang ditunjukkan dari : 1) hasil uji T Pairet Sample Test kelas menggunakan modul lebih meningkatkan kompetensi peserta pelatihan dibandingkan dengan tanpa menggunakan modul, 2) nilai mean post test peserta pelatihan dengan menggunakan modul pelatihan lebih tinggi dibanding tanpa menggunakan modul, 3) pelatihan dengan menggunakan modul cukup efektif sedangkan pelatihan tanpa menggunakan modul tidak fektif. Jadi pelatihan dengan menggunakan modul pelatihan model pembelajaran BCCT dapat meningkatkan kompetensi pedagogik dan profesional Guru dan Kepala TK sebagai peserta pelatihan dibanding dengan pelatihan tanpa menggunnakan modul pelatihan.

\section{SIMPULAN}

Berdasarrkan hasil dan pembahasan serta tujuan penelitian maka dapat disimpulkan bahwa penyelenggaraan pelatihan model pembelajaran BCCT telah dilakukan oleh Yayasan Pesat dan telah menjadi program tetap dua kali dalam setahun. Namun dalam pelaksanaan pelatihan masih ditemukan kelemahan dalam pelatihan, diantaranya peserta kurang memahami materi pelatihan karena tidak adanya buku/ sumber belajar, materi dalam bentuk power point, atau dalam bentuk print out power point atau soft copy, peserta pelatihan hanya berkesempatan 1 kali untuk mengikuti pelatihan, sedang dalam penerapan tidak adanya mentor atau pendamping, dan keterbatasan pelatih yang hanya 1 orang dalam mendampingi Guru dan Kepala TK baik selama pelatihan berlangsung maupun setelah selesai pelatihan. Untuk itu dalam penelitian ini berupaya mengembangan modul pelatihan model pembelajaran BCCT didasarkan tahapan model pengembangan Sugiyono, yaitu:: potensi dan masalah, pengumpulan data, perencanaan desain produk, uji pakar dan calon pengguna, revisi desain produk, pembuatan produk, uji lapangan terbatas , dan revisi hasil uji lapangan terbatas. Hasil validasi ahli diperoleh prosentase rata-rata 86 berkategori sangat baik. Hasil analisa data menunjukkan adanya perbedaan pengaruh penggunaan modul pendidikan dan pelatihan terhadap kompetensi peserta yang yang diukur dari hasil pre test dan post test peserta, dan hasilnya penggunaan modul pelatihan model pembelajran BCCT lebih meningkatkan kompetensi kompetensi pedagogik dan profesional Guru dan Kepala TK sebagai peserta pelatihan dibanding dengan pelatihan tanpa menggunakan modul pelatihan.

\section{DAFTAR PUSTAKA}

Ametembun. 2015. Supervisi Pendidikan - Penuntun Bagi Penilik. Pengawas. Kepala Sekolah Dan Guru-Guru. 9th ed. Bandung: Suri Bandung.

Bano, Vidriana Oktoviana. 2018. "Pengembangan Modul Pelatihan Pengelolaan Penilaian Autentik Guru IPA SMP." Kelola: Jurnal Manajemen Pendidikan 5 (2): 139-51. https://doi.org/10.24246/j.jk.2018.v5.i2.p139-151. 
Branch, Robert Maribe. 2009. Instruction Design: The ADDIE Approach. New York: Springer. https:/ / doi.org/10.1007/978-0-387-09506-6.

Erawati. 2015. "Metode Pelatihan Guru Dinilai Tidak Efektif." https://doi.org/http://helmaherawati.blogspot.com/2015/09/contoh-berbagaijenis-diklatfungsional.html.

Giarti, S. 2016. "Pengembangan Modul Karya Tulis Ilmiah Hasil PTK Berbasis Andragogi Berbantuan CMS Moodle Untuk Peningkatan Kompetensi Guru SD." Kelola: Jurnal Magister Manajemen Pendidikan FKIP. https:// doi.org/10.1017/CBO9781107415324.004.

Ismail, Dkk. 2009. "Competency Based Teacher Education (CBTE): A Training Module for Improving Knowledge Competencies for Resource Room Teachers in Jordan." European Journal of Social Sciences 10 (2): 166-78.

Jackson, J. H., \& Marthis, R. L. 2006. Human Resource Management (Edisi 10). 4th ed. Jakarta: Salemba Empat.

Ngaba, Anggriati Ledu. 2018. “Pengembangan Modul Pelatihan Ptk Berbasis Andragogi Menggunakan Model Addie Untuk Meningkatkan Kompetensi Guru Smp." Kelola: Jurnal Manajemen Pendidikan.

P4TK, Seni dan Budaya. 2009. "Pusat Pengembangan Dan Pemberdayaan Pendidik Dan Tenaga Kependidikan Seni Dan Budaya." P4TK, Seni Dan Budaya. 2009. https:// doi.org/https:/ / p4tksb.kemdikbud.go.id/index.php/berita-pendidikan/78p4tksb.

Perdana, dkk. 2017. "Development of E-Module Combining Science Process Skills and Dynamics Motion Material to Increasing Critical Thinking Skills and Improve Student Learning Motivation Senior High School." International Journal of Science and Applied Science: Conference Series 1 (1): 45. https:/ / doi.org/10.20961/ijsascs.v1i1.5112.

Petriella. 2019. "Pemerintah Segera Bereskan 1,62 Juta Sertifikasi Guru." Https:/ /Ekonomi.Bisnis.Com/Read/20190314/12/899813/Pemerintah-Segera-

Bereskan-162-Juta-Sertifikasi-Guru.

2019. https:// doi.org/https:/ / ekonomi.bisnis.com/read/20190314/12/899813/pemerinta h-segera-bereskan-162-juta-sertifikasi-guru.

Republik Indonesia. 2005. Undang-Undang RI Nomor, 14 Tahun 2005, Pasal 8 Dan 9, Tentang Kompetensi Guru Dan Dosen.

Rindaningsih, Ida. 2012. "Pengembangan Model Manajemen Strategik Berbasis (beyond Center and Circle Time) BCCT Pada PAUD." PEDAGOGIA: Jurnal Pendidikan 1 (2): 213. https://doi.org/10.21070/pedagogia.v1i2.42.

Sadimin. dkk. 2017. "The Journal of Educational Development Developing an E-ModuleBased Classroom Action Research Training Model." The Journal of Educational Development 5 (77): 353-64.

Samsudin, S. 2009. Manajemen Sumber Daya Manusia. Revisi. Bandung: Pustaka Setia.

Sarbeng, I. B. 2013. "Training and Development Interventions and Teaching Performance: Application of Structural Equation Modeling." International Journal of Human Resource Studies. 3: 159-76. https:// doi.org/10.5296/ijhrs.v3i4.4705.

Sari, Nina Permata. 2017. "Pengembangan Modul Pelatihan Konseling Teman Sebaya Untuk Anggota Pmr di Smp Negeri 1 Banjarmasin." Jurnal Ilmiah dalam Implementasi Kurikulum Bimbingan dan Konseling Berbasis Kkni, 4-6.

Sathya. 2017. "Development of Problem Based Learning Training Module in Nursing Education." International Journal of Research in Medical Sciences 5 (5): 1986. https:// doi.org/10.18203/2320-6012.ijrms20171830.

Sitepu. 2013. "Peningkatan Kualitas Guru Menuju Profesionalisme." Https://Www.Beritasatu.Com/Nasional/119109/Metode-Pelatihan-Guru-DinilaiTidak-Efektif. $21 \quad$ Juni. 2013. https:// doi.org/https://www.beritasatu.com/nasional/119109/metode-pelatihan- 
DOI: $10.31004 /$ obsesi.v4i2.512

guru-dinilai-tidak-efektif.

Sugiyono. 2017. Metode Penelitian \& Pengembangan: Research and Development. 3rd ed. Bandung: Alfabeta.

Sumarah, Dkk. 2017. "Pengembangan Modul Pelatihan Model Pembelajaran Van Hiele Dalam Konteks Pendidikan Karakter Untuk Guru SD." Jurnal Penelitian 21 (1): 38-47.

Suradji. 2009. Modul Pendidikan Dan Pelatihan Prajabatan Golongan III (Edisi Revisi III): Manajemen Kepegawaian Negara. Cetakan ke. Jakarta: Lembaga Administrasi Negara 2009.

Suryana, and Fathurrohman. 2015. Supervisi Pendidikan Dalam Pengembangan Proses Pembelajaran. 2nd ed. Bandung: Refika Aditama.

Triananda. 2013. "Metode Pelatihan Guru Dinilai Tidak Efektif." Https://Www.Beritasatu.Com/Nasional/119109/Metode-Pelatihan-Guru-DinilaiTidak-Efektif. 2013. https://doi.org/www.beritasatu.com/nasional/119109/metodepelatihan-guru-dinilai-tidak-efektif.

Wulandari, Mega Retno, and Ade Iriani. 2018. "Pengembangan Modul Pelatihan Pedagogical Content Knowledge (PCK) Dalam Meningkatkan Kompetensi Profesional Dan Kompetensi Pedagogik Guru Matematika SMP." Kelola: Jurnal Manajemen Pendidikan 5 (2): 177-89. https:/ / doi.org/10.24246/j.jk.2018.v5.i2.p177-189. 